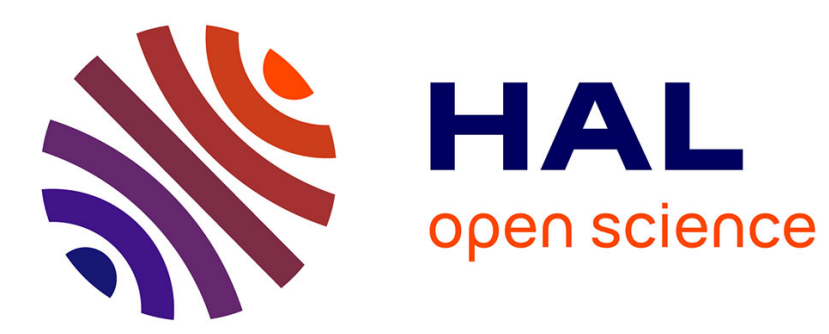

\title{
The Impact of Academic Mobility on the Creation of Localized Intangible Assets
}

Daniel Schiller, Javier Revilla-Diez

\section{To cite this version:}

Daniel Schiller, Javier Revilla-Diez. The Impact of Academic Mobility on the Creation of Localized Intangible Assets. Regional Studies, 2011, pp.1. 10.1080/00343404.2011.571241 . hal-00710053

\section{HAL Id: hal-00710053 \\ https://hal.science/hal-00710053}

Submitted on 20 Jun 2012

HAL is a multi-disciplinary open access archive for the deposit and dissemination of scientific research documents, whether they are published or not. The documents may come from teaching and research institutions in France or abroad, or from public or private research centers.
L'archive ouverte pluridisciplinaire HAL, est destinée au dépôt et à la diffusion de documents scientifiques de niveau recherche, publiés ou non, émanant des établissements d'enseignement et de recherche français ou étrangers, des laboratoires publics ou privés. 


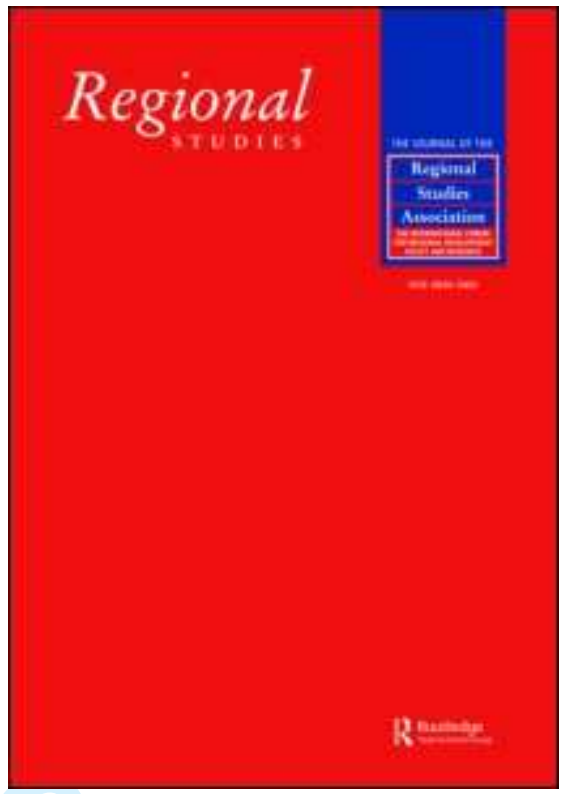

\section{The Impact of Academic Mobility on the Creation of Localized Intangible Assets}

\begin{tabular}{|c|c|}
\hline Journal: & Regional Studies \\
\hline Manuscript ID: & CRES-2009-0356.R2 \\
\hline Manuscript Type: & Special Issue Paper \\
\hline JEL codes: & $\begin{array}{l}\text { R23 - Regional Migration|Regional Labor Markets|Population < R2 - } \\
\text { Household Analysis < R - Urban, Rural, and Regional Economics, } \\
\text { J24 - Human Capital|Skills|Occupational Choice|Labor Productivity } \\
<\text { J2 - Time Allocation, Work Behavior, and Employment } \\
\text { Determination/Creation < J - Labor and Demographic Economics, } \\
\text { J61 - Geographic Labor Mobility|Immigrant Workers < J6 - Mobility, } \\
\text { Unemployment, and Vacancies < J - Labor and Demographic } \\
\text { Economics, R11 - Regional Economic Activity: Growth, } \\
\text { Development, and Changes < R1 - General Regional Economics < R } \\
\text { - Urban, Rural, and Regional Economics }\end{array}$ \\
\hline Keywords: & $\begin{array}{l}\text { star scientists, mobility, local embeddedness, knowledge flows, } \\
\text { intangible assets }\end{array}$ \\
\hline
\end{tabular}

\section{SCHOLARONE \\ Manuscripts}




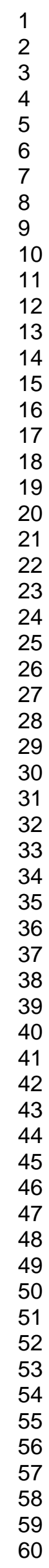 \\ Page 1 of 40} Regional Studies

1

2

4

5

7

8

10

11

12

14

15

16

18

19

20

22

23

25

26

27

29

30

32

33

35

36

37

40

41

42

44

45

46

47

48

50

51

52

53

54

55

57

58

59

60

http://mc.manuscriptcentral.com/cres Email: regional.studies@fm.ru.nl 


\title{
Cris: note that the authors provided the German abstract
}

\author{
The Impact of Academic Mobility on \\ the Creation of Localized Intangible Assets
}

Daniel Schiller, Javier Revilla Diez

Leibniz University of Hannover

Institute of Economic and Cultural Geography

Schneiderberg 50, 30167 Hannover, Germany

Emails: schiller@wigeo.uni-hannover.de,diez@wigeo.uni-hannover.de

\begin{abstract}
Researchers are carriers of significant amounts of knowledge. International academic mobility is thus an important mechanism for inducing interregional knowledge flows. This paper analyzes mobility patterns of star scientists, the rationale behind their mobility decisions, and interrelations between academic mobility and the creation of localized intangible assets. Indepth material from 25 interviews with star scientists in Germany is combined with data from other studies. One major finding of this paper is that long-term mobility of star scientists in the past simultaneously increases the amount of induced knowledge flows and the creation of localized intangible assets.
\end{abstract}

Keywords: Star scientists, mobility, embeddedness, knowledge flows, intangible assets JEL Classification: J24, J61, R11, R23

(Received November 2009: in revised form March 2011) 
Zusammenfassung (German translation of the abstract)

Wissenschaftler sind Träger einer signikanten Menge impliziten Wissens und ihre räumliche Mobilität ist daher ein zentraler Mechanismus, um internationale und interregionale Wissenstransfers zu induzieren. Dieser Artikel analysiert die Mobilitätsmuster von Spitzenforschern, die ihnen zugrunde liegenden Motive und den Zusammenhang zwischen der Mobilität von Wissenschaftlern und der Schaffung lokalisierter immaterieller Vermögenswerte. Dazu wird umfassendes empirisches Material aus 25 qualitativen Interviews mit Spitzenforschern in Deutschland mit den Ergebnissen bestehender Studien kombiniert. Ein wesentliches Ergebnis dieser Untersuchung ist, dass längerfristige Auslandsaufenthalte von Spitzenforschern in der Vergangenheit den Umfang der von ihnen ausgelösten Wissensflüsse erhöhen und damit die Schaffung lokalisierter immaterieller Vermögenswerte fördern.

Keywords (in German): Spitzenforscher, Mobilität, Embeddedness, Wissensflüsse, immaterielle Vermögenswerte 


\section{Introduction}

Highly-skilled people are the most mobile segment of the population worldwide. In Western Europe, more than seven percent of the original number of highly-skilled people have emigrated to another OECD country, whilst for the remaining skill groups, this share is just two percent. Highly-skilled people make up more than one third of immigrants to OECD countries compared to a share in the total labor force of only about ten percent (DOCQUIER and MARFOUK, 2004). Scientists are especially mobile within this group. One third of the most frequently cited researchers in the US are foreign-born. The figures are also high in Western European countries, with the proportions being 24 percent in the UK and 19 percent in Germany (IOANNIDIS, 2004). This high propensity to migrate has initiated debates about the economic effects of gaining or losing researchers. While earlier studies on academic mobility focused on unidirectional flows, i.e. 'brain drain' or 'brain gain', more recent approaches have highlighted the multidirectional nature, leading to 'brain circulation' (Saxenian 2005), which is due in particular to large numbers of academics who migrate temporarily and return to their home countries, i.e. circular migration (OECD, 2008).

From a regional perspective, the spatial mobility and local presence of researchers is important because they are carriers of unique knowledge resources. Large sections of this knowledge stock are tacit (POLANYI, 1966) and cannot be transferred in a codified way, for example via books or manuals. Transfer is, if possible at all, limited to situations in which people work together closely, are able to observe each other's actions and calibrate their communication. In other words, frequent face-to-face contacts are crucial and, as shown in the literature on the subject, diffusion of tacit knowledge remains rather localized (JAFFE et al., 
1993; AUDRETSCH and FELDMAN, 1996; DOERING and SCHNELLENBACH, 2006).

Temporary spatial proximity, for example meetings and conferences, serves only partly as a substitute for everyday contacts since it does not enable the observation and alignment of actions necessary for the diffusion of tacit knowledge. As MAHROUM (2000a) puts it, communication at a distance requires long-term physical mobility due to the fact that knowledge is geographically bound.

Highly-skilled individuals at universities, research institutes and corporate laboratories are termed 'knowledge spillover agents' (KSAs) by MAIER et al. (2007) and BERGMAN and SCHUBERT (2005) because (tacit) knowledge is potentially diffused due to their presence in the region. These mobile KSAs open 'knowledge roads' to other places when sharing knowledge with their peers at other locations around the globe and diffusing it via their interactions with scholars, industrialists, entrepreneurs, staff and students on different spatial scales. If the induced inflows of global knowledge contribute to the creation of localized intangible assets, KSAs truly fulfill a so-called 'antenna function' (FRITSCH and SCHWIRTEN, 1998; REVILLA DIEZ, 2000).

It is argued in this paper that pioneering scientific achievements and outstanding graduates have at least been inspired - if not directly shaped - to a significant degree by the critical endeavours of key figures at certain points in time. Simultaneously, these key figures are important spillover agents when it comes to the transfer of scientific knowledge to new technologies. This notion is supported by ZUCKER and DARBY (2006), who have proven the positive impact of the direct involvement of star scientists on the success of knowledge transfer and growth in start-up biotech firms. By using a more general approach, HOROWITZ (1966) was able to point out the regional economic benefits stemming from a rich depth of scientific talent more than 40 years ago, and more recently, FLORIDA (2002) identified the creative class as a driving force behind the successful development of growth regions. However, studies which explicitly consider the role of distinguished individuals and their 
careers in (regional) knowledge networks and in the accumulation of intangible assets are still rare.

While the concepts mentioned above are rather intensely discussed in the relevant literature, empirical studies in the field are often limited to single modes of knowledge transfer, with most studies using patent citations to measure knowledge flows and inventor's affiliation to measure mobility (MIGUELEZ et al., 2009) or the location of co-authors (FRENKEN et al., 2010). While such focused studies have an advantage in terms of data availability and accessibility by quantitative methods, their coverage of the variety of knowledge flows remains limited. Patents are obviously a measure of codified knowledge production, but the tacit dimension, which is expected to be more relevant in other fields of knowledge production, remains invisible. When using single measures, the analysis is also prone to distortions resulting from differences in dissemination cultures between scientific disciplines. In contrast, this paper applies a more comprehensive approach towards mobility of star scientists and their impact on the localization of knowledge flows.

The aims of this paper are (i) to describe main features of mobility patterns among star scientists in Germany, (ii) to explain these patterns using information about the rationale behind mobility decisions, and (iii) to understand the impact of mobility on the localization of four kinds of knowledge flows induced by star scientists in Germany.

The empirical data were collected using guided face-to-face interviews with 25 senior star scientists in Germany who were asked about their mobility decisions and their spatial scope of scientific, industrial, entrepreneurial, and human capital interactions. While this qualitative and explorative analysis definitely provides a comparison between different knowledge flows and an in-depth understanding of the mobility-localization nexus, it is not able to provide representative measures. However, it is considered to be a relevant contribution with important conclusions for future research in this emerging field. 
Germany has been chosen as a case study for this paper for several reasons. Despite the fact that it is the largest country in Europe, its university system has been less well studied than that of Anglo-American countries. In addition, reforms have recently been introduced to the higher education system with the aim of improving the 'excellence' of universities, and there has been intense debate as to whether German universities and research institutes are able to retain and attract the best researcher in the market. Finally, the size of the country and its spatially diversified industrial structure and administratively decentralized science system provides several spatial options for star scientists to cooperate with partners in different regions.

The paper is organized in four parts. The next section reviews the literature on the mobility of researchers and localized intangible asset creation. Section three presents the data and methods. The fourth section presents and discusses the empirical findings on mobility and localization of knowledge flows for star scientists in Germany. The final section summarizes the main results and provides a perspectives for policy makers and future research.

\section{Mobility of scientists and creation of localized intangible assets}

\subsection{Star scientists, knowledge spillover agents, and knowledge flows}

This section introduces and defines the term 'star scientist' and explains why it is worthwhile for regional science to focus on these distinguished individuals. The term 'star scientist' is not clearly defined in the existing literature. It was used for the first time in an article by ZUCKER et al. (1998). The common understanding is that star scientists are outstanding researchers located mostly at universities, with those in private companies also being included in some definitions (FURUKAWA and GOTO, 2006). Star scientists at universities and public research institutes are a unique group of individuals within the process of knowledge creation. They are more than simply bearers of a significant amount of knowledge. The fact that they are considered stars is also related to their superior visibility and relevance in their 
field of studies. Their diverse activities in basic and applied research, teaching, industrial collaboration and entrepreneurial activities result in manifold opportunities for knowledge spillovers and transfers. In line with other studies (for example ZUCKER et al., 1998, MAIER et al., 2007), star scientists are defined as the most often cited individuals in a respective field of research in this paper. The identification of star scientists is discussed with more detail in section three.

The interest in star scientists by regional scientists stems from their multiple activities in terms of knowledge creation and knowledge diffusion which is reflected by the term knowledge spillover agents (KSAs). KSAs are the agents of knowledge flows within organizations (i.e. firms, universities, government laboratories) and across institutional and spatial boundaries (BERGMAN and SCHUBERT, 2005). KSAs are, broadly defined, highlyskilled individuals who possess the potential to transfer valuable knowledge (locally) and to contribute to the growth of (local and regional) knowledge stocks (MAIER et al,. 2007). Their spatial impact emerges due to inter-regional mobility, direct collaboration, or very close interaction, for example with members of their working group, which enables the transfer of tacit knowledge. However, the specific activities of KSAs receive less attention in the literature than the stocks and flow of knowledge connected to them (BERGMAN and SCHUBERT, 2005).

Knowledge flows induced by star scientists are analyzed according to their impact on intangible assets (IA) creation, i.e. non-material factors that contribute to industry performance or that are expected to generate future economic benefits for the entities or individuals who control their deployment (EUSTACE, 2000; KRAMER et al., 2009). Figure 1 illustrates the potential impact of knowledge flows initiated by star scientists on four kinds of intangible assets, i.e. scientific networks, industrial networks, entrepreneurship, and human capital. 
Scholar-to-industrial flows cover direct collaborations, for example, by contract research, consulting projects, or licensing agreements, and personal transfer from industry to university or vice versa. Direct scholar-to-scholar flows happen in the form of joint research projects or consortia; personal transfer is organized via visiting scholars. Scholar-to-entrepreneur flows are distinct from industrial flows because the star scientists himself is becoming an entrepreneur or is, at least, closely involved during the start-up phase. Scholar-to-student flows are linked to the teaching function of star scientists at universities, but also arise if a talent is attracted from other regions.

The potential of star scientists to serve as KSAs has resulted in several policy measures at different government levels, universities, and research institutes to attract star scientists and retain them at specific locations. These policies are connected with the expectation that the presence of these individuals increases performance measures of the respective university or research institute and positively affects economic development directly or indirectly. Related policy measures are summarized by the term brain competition policy (REINER, 2010) and are discussed in more detail in section five.

\subsection{Mobility of star scientists}

The mobility of skilled people spreads knowledge at the local and regional level (OECD, 2008). MAHROUM (2000a) has shown that scientific mobility is the main component that expands and links the different spaces within a particular scientifc tradition and is the major mechanism of the growth and decline of centers of scientific gravity. Compared to other forms of human capital, mobility is a normal part of the scientific life (MAHROUM, 2000b). Mobility is categorized into mobility between different locations (spatial mobility), the progression of academic careers from being a doctoral student to full professorship (career 
mobility), and changes between positions at university and in industry (institutional mobility). The focus of this chapter is on spatial mobility, since star scientists are expected to be highly mobile internationally, and spatial mobility is closely connected with career mobility, especially during the early stages of a career. In the case of Germany, institutional mobility is expected to be less likely than mobility within the university system (LAM, 2007).

Motivations for mobility in the academic sector could be related to scientific, economic, cultural and personal factors. Up to now, there has been no definite empirical evidence on the motivations behind the mobility of star scientists. In the empirical part of the paper, results from surveys of the highly skilled in general will be presented. It is expected that nonpecuniary scientific factors, such as the quality of the university, the availability of research budgets, personnel and material research infrastructure, are more important than economic factors, such as personal income, when compared to job movers outside academia (JÖNS, 2007; DTI, 2002). Due to the rising demand of scientific labour, reputation for scientific quality and openness is the critical factor to attract excellent researchers (MAHROUM, 2000b). However, economic determinants, particularly differences in wage levels and career opportunities, are also relevant for scientific mobility. Concentration effects are also important; talent is attracted by talent, since creative processes are not carried out in isolation (SOLIMANO, 2008). This effect is also related to soft-factors, e.g. cultural affinity, living environment, and personal motives as discussed by FLORIDA (2002). The impact of scientific mobility has been highly debated in the literature on brain drain and brain gain. However, more recent approaches have emphasized the fact that effects of scientific mobility are not necessarily unidirectional. The concept of brain circulation (SAXENIAN, 2005) points out the bi- or multidirectional nature by acknowledging the fact that backward linkages to the home region often remain intact and that the length of stays is decreasing. Knowledge migrants thus have the unique opportunity to blend existing skills with knowledge acquired during stays abroad and to apply it in scientific or entrepreneurial contexts at other locations, 
most likely their home countries (e.g. SAXENIAN, 2006). To summarize, mobile star scientists have the potential to create 'knowledge roads', which enables the integration of spatially distant areas (MAIER et al., 2007).

Outward migration of star scientists from many countries is to the US. As a result, the migration balance of all other countries is negative, with only two exceptions: France and Switzerland. When comparing the place of birth and the place of work of star scientists in the 'ISIHighlyCited.com' database, inward migration has increased the number of star scientists in the US by $50 \%$ while Western European countries have lost a third of their star scientists. Within Western Europe, mobility is much lower than between Western Europe (without the UK) and the US. Only 13\% of star scientists in Western Europe were born in another Western European country. Switzerland, France, Germany, and the Netherlands are the countries with a positive internal migration balance, while Italy has the highest rate of loss (MAIER et al., 2007). Inward and outward migration of academics in Germany follows distinct patterns. While most emigrating German academics move to the US and Western Europe, most inward migration originates from Central and Eastern Europe and Asia. The US is easily the most important country for time spent abroad by German academics in general (DAAD, 2007).

The mobility decisions of scientific talent are made on the basis of push- and pull-factors based on four current empirical studies. Mobility motives of German scientists are ranked in Table 1. In addition, the survey by DETTLING and JÖRGENSEN (2004) shows that only $18 \%$ of German scientists abroad ruled out a possible return to Germany, whereas $49 \%$ considered it to be possible, and 33\% said it was very likely. In general, dissatisfaction with research conditions in Germany and incentives of foreign countries are the most important factors for young researchers to leave Germany, at least temporarely.

\footnotetext{
$===$ Insert Table 1 about here $===$
} 
The research question derived from the discussion above is as follows:

Question 1: Which factors are behind the international mobility of star scientists in Germany, especially during early stages of the career?

\subsection{Mobility of scientists and the localization of knowledge flows}

While it is quite easy to summarize the ways in which star scientists potentially affect the creation of knowledge, it is greatly debated as to what degree these effects occur at a local level. What kind of interdependencies between star scientists at universities and public research institutes, innovation, and value creation can be found in the literature on the subject? Are all three necessarily linked together within a regional innovation system? The answer given by POWER and MALMBERG (2008) in their recent essay is as expected: yes and no. The spatial scope of knowledge flows depends on regional characteristics, for example the availability of industry partners. Moreover, direct linkages between science and industry do not follow a particular spatial logic, while activities initiated by technologytransfer offices are often designed with this purpose in mind (SIEGEL et al., 2007).

In the case of Germany, administrative units differ markedly in size. For example, if federal states were used as the regional level, the city states of Hamburg, Bremen, and Berlin would be separated from their hinterland, which usually hosts most of the industries. An exact distance approach, as in BEISE and STAHL (1999) or MORENO et al. (2005), is thus applied in this paper. A local link of a star scientist is restricted to a $100 \mathrm{~km}$ radius around their host institution. This distance is suggested by FRITSCH and SLAVTCHEV (2005:12), who noted that there is hardly any location in Germany which is farther than $100 \mathrm{~km}$ from the next research university.

A focus on individual star scientists has the potential to differentiate between several channels for knowledge flows. Star scientists act simultaneously on local, national, and global scales. While scientific endeavours are carried out globally, they may have a local impact if 
collaboration partners, for example colleagues at their university or firms at the same location, are available - the so-called antenna function (FRITSCH and SCHWIRTEN, 1998; REVILLA DIEZ, 2000). The involvement of star scientists in innovation might lead to spillovers and benefits for some proximate firms and entrepreneurs, for example in the case of university spin-offs. Other forms of knowledge flows, such as interactions between scientists and existing firms via consultancy or contract research, are more or less dependent on the given localization of industrial demand and trust-based networks among the partners. Whether or not the education of students has an impact on the provision of human capital for the local labor market is also related to regional labor demands. University towns are an obvious example of the difficulties involved in retaining graduates locally. Therefore, interaction patterns cannot be expected to follow a spatial logic per se, but the presence of an industrial concentration in a particular field with strong interactions between universities and industry could be an incentive for star scientists to migrate to that location, attracted by superior research conditions including funding opportunities and potentials for collaborations.

International mobility is expected to have an impact on the spatial scope of knowledge flows induced by star scientists. To structure their manifold local, interregional, and international interactions, MAIER et al. (2007) distinguish between 'initial knowledge flows' and 'subsequent knowledge flows'. They argue in their knowledge link model that the initial flow based on the pure movement of star scientists from one region to another is far from sufficient to cover the variety of subsequently induced knowledge flows. These subsequent knowledge flows are summarized above in Figure 1, with the way in which they contribute to the creation of intangible assets having already been discussed. Regarding the spatiality of these flows, MAIER et al. (2007) expect that star scientists create 'knowledge roads' between the sending and the receiving region, for example through team members or students who follow them and by maintaining linkages to key figures in the sending region. 
Besides its regional impacts, scientific mobility is also interrelated with career paths and the productivity of star scientists themselves. A study on patenting and publication activities of mobile scientists (DIETZ and BOZEMAN, 2005) revealed that some career diversity, i.e. a certain time spent outside academia, is positively related with both patent and publication productivity. But too many institutional job changes during the career, i.e. a weak institutional embeddedness, negatively affect productivity. If this finding is applied to spatial mobility, it is expected that a sufficient degree of regional embeddedness has a positive impact on the productvitiy of scientists.

Knowledge sharing is not a zero-sum game due to the non-rivalry in using most kinds of knowledge. In general, therefore, star scientists have a positive impact on intangible asset creation in the receiving region if a certain amount of their knowledge flow is embedded locally, i.e. for the benefit of local researchers and companies. At the same time, the international academic mobility of star scientists has a positive impact on the creation of intangible assets, regardless of the spatial scope of knowledge flows, if mobility results in greater or more intense knowledge flows, for example due to the integration in global knowledge networks. The impact of academic mobility on the creation of localized intangible assets is thus positive if mobile star scientists induce greater or more intense local knowledge flows than non-mobile star scientists.

SCHILLER and REVILLA DIEZ (2010) recently analyzed the embeddedness of knowledge flows initiated by star scientists in Germany. They could not confirm the expectation of a predominantly local scope. The impact on the local area was especially low for industrial collaborations. Based on this finding and the discussion above the second central research question is as follows:

Question 2: What is the impact of longer stays abroad on the overall activity and the local embeddedness of star scientists in Germany? 


\section{Data and methods}

In this paper, star scientists are defined in two ways: (i) the most frequently cited researchers in a specific discipline and (ii) coordinators of clusters of excellence within the German 'Exzellenzinitiative'. This approach was chosen in order to avoid the bias related to using only a single group. The focus was placed on the disciplines of science and technology, since they are expected to have the greatest potential for industrial collaboration and entrepreneurial activities.

The first group comprised those researchers who are most frequently cited in their discipline and who are located in Germany. Citations are a widely applied comparative measure for academic excellence in most subjects. The citation database 'ISIHighlyCited.com', provided by the 'ISI Web of Knowledge', is used to identify frequently-cited star scientists as applied by related papers (c.f. FURUKAWA and GOTO, 2006; ZUCKER and DARBY, 2006; MAIER et al., 2007). At the time of study, the basic population of frequently-cited researchers in these fields in Germany was 169. A stratified randomized sample of 50 star scientists was drawn separately for each scientific field listed in Table 2; 10 scientists were drawn from each field. 19 agreed to an interview. Two important limitations are connected with the use of citation data. Firstly, higher citation ratios are more likely to be reached by researchers focusing on basic research. Secondly, the number of citations increases constantly over the course of an academic career, which means that younger researchers are systematically underrepresented in the sample.

The second group comprised the coordinators of 20 clusters of excellence at German universtities and research institutes. The clusters of excellence have been jointly selected in a competition by the German Research Foundation and the German Council of Science and Humanities in 2006 and 2007. They comprise of departments at universities, public research institutes, and private companies. Each cluster receives funding for six years. The coordinators had to be scholars with an excellent reputation in their field, and they were 
significantly younger than those listed in the citation database (an average age of 52 as opposed to 60 years). All 20 coordinators of the centers of excellence were contacted. 6 agreed to an interview. Table 2 provides information on the sample with respect to the position and the discipline. 21 star scientists had their primary affiliation with a university in Germany, two at public research institutes and two at private companies. However, at least four star scientists at universities held joint positions with Max-Planck-Institutes. Only three interviewees never worked abroad during their career and the sample does not include any non-Germans which reflects the low attractiveness of Germany as a host region for star scientists.

It has to be mentioned at this point that each selection criterion for star scientists has its pros and cons. The selection based on citations is the most commonly accepted way to identify star scientists, but it is only based on a single indicator and obviously favours older scientists who were able to accumulate citations over a longer period of time. Therefore, a group of younger scientists, who were evaluated based on several criteria during the cluster of excellence competition, was added. It was also considered to include a group of junior research group leaders in their 30s, but none of these researchers spent sufficient time abroad to allow for an analysis of the impact of mobility on local embeddedness. Finally, the sample of 25 star scientists at medium to advanced stages of their career is considered to be very useful to explore the overall impact of mobility on localization in retrospective. But some caution is necesseray if the results are applied to forecast the patterns of younger scientists.

$===$ Insert Table 2 about here $===$

The data collection and analysis is based on a qualitative approach which was chosen because of the novelty of the research topic and the diversity of knowledge flows induced by star scientists. It has been shown in previous studies (SCHILLER and REVILLA DIEZ, 2010) that 
the excellence of star scientists manifests itself in several ways. By qualitative interviews the wide portfolio of activities was covered in a more comprehensive way than it has been done in quantitative studies which, for example, are focussed on the spatiality of publications and citations (FRENKEN ET AL., 2009). In addition, a qualitative approach promises to add evidence on informal modes of knowledge flows since quantitative studies are mainly based on formally documented knowledge spillovers.

The information was gathered using guided interviews of 60 to 90 minutes in length conducted from July to September 2008. They were each carried out by one interviewer, and were recorded and finally transcribed in summarized protocols. Five main topics were covered: (i) academic career and mobility decisions, (ii) scientific collaboration, (iii) industrial collaboration and entrepreneurship, (iv) graduates and work group members, (v) universities and local development. For scientific and industrial partners, information about the location (city), the method of establishing contact and the content of the cooperation was gathered. Interviewees involved in entrepreneurial activities were asked about the location of the new companies, the persons involved in the foundation, and ongoing collaborations with the company. Regarding the work group, the central focus was on recruitment of $\mathrm{PhD}$ students and postdoctoral fellows, and on tracing their subsequent careers. Additional material was obtained from CVs and other publicly available information on each interviewee. Some parts of the interviews were categorized and summarized, for example regarding the spatial scope of activities (local, national, international), while others were assessed via content analysis (MAYRING, 2008). The required categories were extracted by inductive coding to ensure an unbiased reproduction of the interview material. Because of the qualitative approach, the results are not used for analytical generalizations. However, it seems to be a feasible way of exploring transfer channels and the potential impact of the multiple activities of star scientists from a broader perspective. 
4 Empirical results on mobility and localized knowledge flows of star scientists in Germany

4.1 Mobility patterns and motives

Most of the star scientists interviewed for this paper returned to Germany after working abroad for a certain time in their early career. Only three of them had never been abroad for a period longer than six months. $44 \%$ had held one position in another country, while another $44 \%$ had even held two or more different positions abroad before returning to Germany. About two-thirds of them had spent a part of their career in the US. Other important destinations mentioned three or more times were the UK, France, and Canada. This confirms recent results on the net migration balance for scientists in Germany, which is supposedly positive as most emigrating Germans only stay abroad for a period of less than two years (KOPPEL and PLÜNNECKE, 2008). More than one-third of the interviewees had held a position in industry in the past, which puts LAM's (2007) expectation of a lower institutional mobility in hierarchical university systems, such as Germany, into perspective. It is also a confirmation of the assumption that direct exposure to industrial environments is beneficial for academic productivity in science and technology disciplines.

Motives for mobility mentioned by the star scientists interviewed in Germany are very diverse, but some generalization is possible. The most common reasons for going abroad are

- to work and study at places with a very high reputation in their discipline, which might or might not be in Germany,

- to acquire an international qualification which is (sometimes) a prerequisite for a career in Germany,

- to tap into existing international networks of supervisors or mentors, and

- the sheer interest in living in another country.

It is quite common that the careers of star scientists are not the result of thorough planning, but of fortunate coincidences at certain points in time. Most time spent abroad began with the clear intention of returning to Germany after a certain period of time; however some stayed 16 
longer and even obtained tenured positions at US universities. Brain circulation is thus likely to appear in academia.

Motives for returning were often a combination of the following factors:

- better equipment and more personnel for conducting research

- better access to German funding bodies than to those in the US

- more opportunities to define own priorities in research

- the status of civil servants and the possibility of becoming tenured, even though a recent reform of the remuneration system has resulted in decreased basic incomes and was criticized by the interviewees for its negative effects on attracting excellent researchers.

It has been mentioned by researchers who worked as a professor abroad, that personal incomes in Germany are often lower than in other countries, but the factors mentioned above were more important for the decision of returning to Germany. In general, personal motives have been mentioned very often as the decisive criteria for returning to Germany. Preferences of the spouse, other family ties and familiarity with the culture are among the most frequently mentioned personal reasons. The attractiveness of the city in which the university is located was mentioned in very few cases. If other soft factors are mentioned, they are related to greater emotional proximity to the original home region or Germany in general.

The intention to leave Germany in the future was rather low among the star scientists interviewed which is not surprisingly given the average age of the interviewees. But for the younger researchers in the sample, a critical reason to stay at the present location was the possibility of finding scientific cooperation partners at the university or at public research institutes in the region for joint projects. Max-Planck and Fraunhofer Institutes were explicitly mentioned. Star scientists, therefore, do not just have potential impacts on their regional environment, as discussed in the next section. Regional embeddedness is also an important factor in prolonging the tenure of star scientists at their present location. 
Since the average age of the senior star scientists was 58 years, it can be concluded that international mobility has always been very important for the best scholars in Germany and that brain circulation has been an important mechanism for initiating knowledge flows in German academia for a long time. Nevertheless, the current German debate considers outward migration to be a rather recent development which indicates a weakness of the public research system and entails a loss of knowledge. Many star scientists pointed out that temporary international mobility had already been a prerequisite for a subsequent academic career in their discipline in Germany at that time. Some of the older researchers mentioned that their stays at excellent research institutions had given them access to the latest research equipment in their field which had not been available in Germany at that time. Thus, the recent debate on brain drain and brain gain is not necessarily related to a new phenomenon, but rather to the fact that more attention is paid to this phenomenon by academics and policy makers recently. Furthermore, it is expected that the overall mobility patterns of older scientists might even be applicable for younger scientists today.

\subsection{International mobility and local embeddedness}

This chapter links the mobility patterns and motivations of star scientists in Germany, which have been discussed above, with their spatial embeddedness and their creation of localized intangible assets. It will be investigated (i) whether star scientists are more active knowledge spillover agents after longer stays abroad than after shorter or no stays abroad, and (ii) whether star scientists have a lower local embeddedness at their present location after longer stays abroad than after shorter or no stays abroad. These questions are analyzed according to generalized findings from the interviews in this section and three typical cases of star scientists with different mobility histories in the next section.

The conceptual discussion revealed that star scientists induce multi-dimensional knowledge flows; the main flows used to structure this section are those within the scientific community 
(scholar-to-scholar), between science and industry (scholar-to-industrialist), entrepreneurial activities (scholar-to-entrepreneur), and training, mentoring and inspiration of staff and students (scholar-to-student). As a first step, the 25 senior star scientists were split into three groups by calculating the time that each of them had spent abroad in their career by considering all locations from their time as a $\mathrm{PhD}$ student onwards. Highly mobile scientists were those who had spent more than three years outside Germany, mobile scientists those who had spent up to three years abroad, and non-mobile scientists were those who had never held a position in another country. The time period of three years was used as a threshold because shorter stays are usually limited to single career steps, for example doctorate, postdoc, or visiting fellowships, while longer stays are connected with an in-depth integration abroad, for example as a professor. Table 3 shows the spatial scope of knowledge flows for each group which is the result of a categorization of the interview material. This table is not meant as a quantitative analysis, but as an illustrative summary of the qualitatitive material which is discussed seperately for each knowledge flow below.

\section{$===$ Insert Table 3 about here $===$}

Surprisingly, a longer period abroad did not have a negative impact on the localization of scholar-to-scholar knowledge flows. On the contrary, especially highly mobile scholars indicated that they were actively trying to combine their international networks with scientific interactions at their current institution which results in a bipolar global-local interaction pattern partly at the expense of linkages within the German community beyond the recent location. The group that stayed abroad for shorter periods is also oriented towards the international community, but embeddedness at their current location is much weaker while they have better contacts at the national level. 
The major channels for localized scientific collaboration of star scientists are the collaborative research centre (CRC) scheme (Sonderforschungsbereich) of the German Research Foundation (DFG) and the 'clusters of excellence' funded by the excellence initiative. The CRC scheme funds research related to a broader interdisciplinary topic which is carried out by several research groups at one location. The scheme requires a strong scientific coordinator and a critical mass of excellent research around the respective topic. Highly mobile star scientists are comparatively often involved actively as coordinators of CRCs at German universities. They thereby benefit from their previous experience in large international research consortia and their visibility. The 'cluster of excellence' scheme is very similar to the CRC scheme in the sense that it is based on a localized critical mass of excellent research in a certain scientific field. Both schemes are vehicles to involve mobile star scientists effectively in local scientific collaboration. The large amount of funding and the prestige related to these schemes are mentioned as the main incentives to initiate projects under these schemes.

Scholar-to-industrialist knowledge flows are the least localized activity of star scientists. Mobility does not have an impact on the (weak) local embeddedness. With the exception of non-mobile star scientists, the main spatial impact of industrial collaborations is found at the national (slightly mobile star scientists) and international level (highly mobile). Especially many of the highly mobile star scientists have established close contacts to foreign firms during their stays abroad or even worked at these companies previously. The major explanations derived from the interviews for this delocalized spatial pattern are as follows: (i) the spatial distribution of university research and companies with knowledge demand in related fields do not overlap. (ii) The selection of partners is based on their quality rather than on their location. Star scientists actively look for industrial partners who are technological leaders and who possess the absorptive capacity and financial resources to establish meaningful collaborations. These firms are more easily found on the national or even global stage. (iii) Potential local partners are not interested in collaboration with universities. Some 
interviewees mentioned the reluctance of large German companies to collaborate with universities, for example, due to a mismatch of the research focus of particular institutes at the local university or an explicit strategy of foreign firms to restrict cooperation with universities to their home country. (iv) In several cases, the localization of industrial collaborations is higher for small and medium-sized enterprises or spin-off companies.

Scholar-to-entrepreneur knowledge flows and entrepreneurial activities, for example spin-off formation, are the most localized activities of star scientists. The activity level is much higher among highly mobile star scientists than among slightly mobile stars: 9 of 12 highly mobile stars have founded a company by themselves, whereas only 1 of 9 slightly mobile stars has done so. Experiencing an international research environment was apparently connected to the attitude towards entrepreneurship. The risk-taking attitude of the interviewees might be an unobservable characteristic that had an impact on the decisions to go abroad for some time and to become an entrepreneur. In addition, the literature provides a large amount of evidence for a high relevance of academic spin-offs at certain locations in the United States, which is not resembled at any location in Continental Europe (WRIGHT et al., 2007). This might have influenced the attitude towards entrepreneurship of scientists that stayed abroad for some time. Other papers support the high localization observed in the sample (STAM, 2007).

Star scientists are expected to have a strong influence on staff and students working in their research teams. Scholar-to-student knowledge flows have the highest potential for enabling the transfer of tacit knowledge by working closely together every day. All star scientists direct large research units and have trained, mentored, or inspired several students and staff members during their career. The largest research unit in the sample consists of about 100 staff members. A major channel for initiating global-local knowledge flows is the recruitment practice of star scientists. As shown in Table 3, local recruitment is important regardless of the time spent abroad. Among all mobility classes, scientists' own graduate students are very often employed as $\mathrm{PhD}$ students. Principal reasons include the specific skills acquired during 
their graduate studies and the better screening of candidates in one's own graduate program. However, highly mobile star scientists regard international hiring as being just as important as local hiring. They attract much more international talent, and once those individuals have been attracted to a specific region by the star scientist, they potentially embed themselves locally, too. Additionally, benefits from different scientific backgrounds are much greater in such international groups. An increased performance of mixed research groups was explicitly mentioned as the major reason behind international hiring practices by the interviewees in many cases. Since the number of international staff at German universities is rather low (SCHILLER, 2011), international recruitment strategies have the potential to overcome this perceived weakness. Contacts to former workplaces and colleagues abroad and the high visibility of star scientists make their groups potentially attractive for young scientists from abroad. The experience of highly mobile star scientists with an international research environment allows them to handle the remaining institutional and cultural barriers in the German science system for the recruitment of foreign researchers, in particular those from non-EU countries.To summarize these general results, no trade-off is found between international mobility and local embeddedness. On the contrary, an antenna function is especially predominant for scholar-to-scholar and scholar-to-student interactions by highly mobile star scientists. At the same time, less mobile star scientists more rarely combine global and local interaction and thus do not utilize the full potential of acting as knowledge spillover agents in a spatial sense. Their activities are sometimes almost exclusively international, for example scholar-to-scholar, sometimes almost exclusively local, for example scholar-tostudent. Localized entrepreneurial activity is another channel frequently used by highly mobile scientists to inject international scientific knowledge into the local economy. At the same time, the localized impact of industrial collaboration is rather coincidental in all mobility groups. If leading firms in technology fields related to the specialisation of a star 
scientist are located in the region, locally-embedded university-industry linkages are rather likely, but most knowledge flows occur at the national or international level.

\subsection{Case studies of mobile and non-mobile star scientists}

The generalized observations in the previous chapter are complemented by three cases of star scientists. The selection criteria were (i) the amount of time spent abroad, one representative was selected from each group in Table 3, and (ii) a portfolio of activities and interactions related to most of the four types of intangible assets in Figure 1. Several individual peculiarities are also highlighted to show the diversity of knowledge flows induced by star scientists. The three cases also cover different scientific disciplines (natural science, engineering, and computer science).

The highly mobile Professor A

Professor $\mathrm{A}$ is a physicist who received his $\mathrm{PhD}$ from a university in Hesse and moved to a public research institute in France where he spent six years. He spent another year in England and one year at a German public research institute before he took up his first position as an associate professor at a technical university in the western part of Germany. After three years, he moved to his current position (full professor) at a university in a large city in the eastern part of the country. Since then, he has spent long periods abroad as a visiting professor and as a guest professor at a company research laboratory in the US. Professor A has worked at his current location for 17 years. The main reasons for his move to France were the challenge of setting up a new laboratory directly after getting his $\mathrm{PhD}$, in combination with private and cultural affinity. He always planned to return to Germany as a professor because the equipment at German universities is better than, for example, the US, where the individual payment is more attractive though. But the decisions in favour of the universities where he received his first and his current position were rather coincidental. These positions happened 
to be available when he was looking for a professorship; a statement made by several scientists when asked about their mobility decisions within Germany.

Professor A follows two distinct collaboration strategies. He specifically tries to collaborate locally with scientific partners and by supporting spin-off companies. At the same time, he tries to work with the best partners regardless of their location. His industrial collaborations with large companies are mainly located abroad and he hires his key staff internationally. In his opinion, knowledge flows are most efficient if they are connected with personnel mobility, for example to his group from abroad or to the local industry by spin-off formation. Locally, he is mainly involved in scientific collaboration as the spokesman of a collaborative research center, the director of a research institute with about 150 staff members and a technology center within the university. In particular, he mentioned the good research environment in his city and the availability of excellent scientific partners locally as reasons for his strong local involvement.

He is a typical case for highly-mobile scientists in the sample since he combines local and global knowledge flows in innovative ways. However, he is a special case due to the synergetic combination of the latest basic research and an active involvement with local outlets for his applied research.

The slightly mobile professor B

Professor $\mathrm{B}$ is a chemical engineer who received his $\mathrm{PhD}$ from a German university and worked in the research laboratory of a Japanese company for two years in Japan and for five years in Germany. When returning to academia, he turned down a professorship in Switzerland and moved to a university in Bavaria, where he spent five years, before moving to his current university in another city in Bavaria. Professor B has worked at his current location for six years. He started working at a private company because he was unsure as to whether he was prepared for an academic career. After some years, he felt that he wanted to 
do more in-depth research than in the company laboratory. He was offered two positions in Switzerland and Bavaria at the same time. He chose the position in Bavaria because he was offered a larger research team and because his wife had advantages in the German labor market. However, he did not sense a true appreciation of his work at the first university and moved to the current position, also in Bavaria, soon after.

Professor B is the spokesman of a cluster of excellence at his university, which is also his main local scientific collaboration. Before that, he did not have a lot of local interactions. Recently, he has been more focused on developing international scientific collaborations. His industrial partners are the large players and national champions in his field of research. There are almost no local partners. He is not interested in entrepreneurial activities and there are no spin-offs from his group because his graduates prefer jobs in large companies. New staff members are mainly recruited from his own graduate students, combined with a few international hirings. In contrast to Professor A, he explicitly said that creating an impact for the local economy was not part of his job. Professor B is typical for the group of slightly mobile scientists because of his national focus in industrial collaborations, his local hiring strategy, and the lack of entrepreneurial activities. However, since he was involved in the preparation of the cluster of excellence initiative, he has recently been collaborating closely with scientific partners locally for the first time.

The non-mobile professor $\mathrm{C}$

Professor $\mathrm{C}$ is a computer scientist who received his $\mathrm{PhD}$ from a university in Bavaria where he also spent three years as a postdoc. He became a professor at another university in Bavaria, but returned to the first university after six years. Professor $\mathrm{C}$ has been working at his current location as a professor for 20 years. After finishing his $\mathrm{PhD}$, he was asked to begin an academic career at the institute of his supervisor. He was interested in doing more research and decided, without any specific reason, to stay. After finishing his postdoc, he received an 
offer from a prestigious university in the US, but turned this down because he was married, had young children, and was deeply rooted in Bavaria. Instead, he became a professor at another university in Bavaria. After the retirement of his former supervisor, he received an offer of returning to the previous university. Even though another university in the western part of Germany offered him a post as a director of a larger and more famous institute which was very well equipped, he decided to stay in Bavaria because his wife preferred the quality of life there. Later, he rejected offers from German and Austrian universities because he feared that he would not be able to establish a similarly well-functioning institute for a second time.

Professor C cooperates mainly with scientific partners internationally; he even inherited several of these contacts from his former supervisor. Over the last ten years, he has increased his local collaborations and he now regards science as a potential driver of the local economy. In connection with this, he changed his research focus from basic research to applied research. He chooses his industrial partners according to their excellence. He works almost exclusively with large companies. Many of them are located close to the university or at least in Bavaria. His main spatial scope for industrial collaborations is thus local. Professor C's group created four spin-offs which are located close to the university. His group at the university consists of almost 100 staff members who were mostly recruited from his own students or from related local programs. Only one third of his staff members are from other cities. Non-German staff members are mostly hired from Eastern Europe.

For ten years, Professor $\mathrm{C}$ has regarded himself as a scientist who tries to use his work to create a positive impact on the region. His mobility motives are rather typical for the group of less mobile scientists. In contrast to other less or non-mobile star scientists, however, he is able to link global and local knowledge without having been abroad by shifting from internationally-oriented basic research in his early career towards applied research and close cooperation with industry and local partners in his later career. The unusually high 
localization of his industrial collaborations, though, is rather due to the fact that Bavaria is the location of many relevant companies in his field.

\section{Conclusion and outlook}

In this section, the most important findings regarding the two reserch questions are highlighted and policy instruments to attract star scientists are discussed by assessing the German situation against international best practice. Finally, a brief outlook on future research perspectives is provided.

Question 1: Which factors are behind the international mobility of star scientists in Germany, especially during early stages of the career? The interviews have shown that most of the star scientists spent a considerable period of time abroad during their career even though most of the interviewees are in their late fifties or sixties. It is thus concluded that international mobility is not a new phenomenon for the young generation, but has always been an important element of succesful careers of German researchers. However, most careers of the interviewed star scientists were not the result of thourough planning, but of fortunate coincidences. On the one hand, the decision for a certain location abroad was not only based on the reputation of the host institution, but existing personal networks of supervisors or mentors were critical factors in many cases. On the other hand, the latent interest to return to Germany was often finally activated by personal motives. They were also a critical factor for selecting a certain university in Germany, even though the quality of the research environment with regard to funding and equipment and the secured employment as a civil servant were other major factors.

Question 2: What is the impact of longer stays abroad on the overall activity and the local embeddedness of star scientists in Germany? The most important finding with regard to the impact of mobility on embeddedness is that the highly mobile star scientists among the interviewees had very intense local collaborations with other researchers in addition to their 
international networks. They often used the so-called collaborative research centre scheme (Sonderforschungsbereich) of the German Research Foundation. However, the integration of global and local networks was partly at the expense of a more comprehensive integration within the national scientific community in general. Less mobile scientists more frequently collaborate on a national level.

The interviewed star scientists were not only focussed on scientific excellence, but maintained industrial collaborations in almost all cases regardless of their mobility. Most of them were not oriented towards the local economy in particular, but had linkages to the best companies in their respective field of expertise at the national and sometimes international level. Mobility did not have a major impact on the local embeddedness of industrial collaboration, but highly mobile scientists often developed close contacts to international companies. Only some star scientists mentioned an explicit interest in working with local small and mediumsized enterprises.

The exposure to an international research environment and the need to act more entrepreneurial, for example at universities in the United States, co-occurred with more entrepreneurial activities among highly mobile star scientists. Entrepreneurial activities most often occur at the local level.

Staff and students are also most often recruited locally by all star scientists, but this is complemented by a much higher number of international hiring, often from former places of work, by highly mobile star scientists. Thus, some of these working teams really became seed beds for further interactions among staff members.

Assessment of policy instruments to attract star scientists: Since international mobility is a normal feature of science systems, policy makers are advised to treat it as an opportunity to gain access to international knowledge networks, and not as a threat to lose knowledge to other regions. Policy efforts to attract, educate, and circulate human capital in general and star scientists in particular are summarized as brain competition policy (BCP) by REINER (2010). 
As a cross-sectional policy field, BCP addresses several traditional policy fields, especially at the interface of immigration policy and science and innovation policy. At the international level, Mahroum (2005) has reviewed different policies and identified some features of best practice approaches with regard to these policy fields.

The assessment of science and immigration policy in Germany is based on the interviewed star scientists, on MAHROUM's (2005) policy analysis, and on PRITCHARD's (2006) paper on the restructuring of the German universities. Germany is still well known for its strict immigration policy and regulated labor market (MAHROUM, 2005). Recently introduced measures to liberalize the immigration of highly-skilled workers seem to be insufficient since they are limited to extremly well paid positions and do not increase the inflow and retention of junior scientists. Particular problems are related to the retention of students after their graduation due to strict labor market regulations. The German science system itself is regarded as rather inflexible with highly regulated academic career structures, less autonomy in terms of hiring policies, and a national outlook (PRITCHARD, 2006). Academic mobility is therefore often carried out via structured exchange programs (MAHROUM, 2005).

The interviewed star scientists most often mentioned that the new payment scheme for professors which reduces the basic income and adds limited performance-based top-ups is not attractive enough to attract the best scientists. Other issues that were frequently mentioned as disadvantages to attract reesarchers from abroad are a lack professionalization within the university management, too much bureaucracy and too less freedom and trust for researchers, the need for more competition and performance orientation, and high teaching loads of professors (eight to ten hours per week). Legal restrictions to do research in certain research fields, for example in life science, were also mentioned as a barrier.

However, it has been acknwoldged by most interviewees that recent reforms are helpful to improve the situation. The excellence initiative which provides funding for institutional strategies of so-called elite universities, clusters of excellence, and graduate schools is 
mentioned as a useful way to provide additional funding based on performance and competition. These programs and other established schemes to fund larger research consortia, like the collaborative research centers of the German Research Foundation, were an opportunity to attract researchers from abroad in some cases, but mostly limited to returnees. Other initiatives like a scheme of the federal state of North Rhine-Westphalia to attract German nanoscientists from abroad and network initiatives like the GAIN network for Germans in North America are other recent examples of policy actions that increase the potential to tap into international knowledge sources.

To conclude, brain competition policy in Germany should adress the issues of immigration, labor market access, and science system reforms in a more coherent manner. There is much more awareness for the attraction of talents from abroad today, but policy actions are still few and isolated.

A need for future research has been identified in three fields. Firstly, better data sets are needed for an efficient mapping of the mobility of researchers and star scientists. This would allow the development of more robust measurements of the supposed brain drain from European countries. Secondly, the application of a broader definition of knowledge spillovers and its combination with the impact on intangible assets has been a viable method of measuring the impact of star scientists. However, the qualitative approach used in this paper should be complemented by quantitative analysis. Thirdly, this explorative analysis has only covered star scientists in Germany. In order to compare the mobility motives and regional impacts, other European countries should be included in the analysis, and European scientists in the US should be used as a comparison group. Furthermore, non-star scientists and researchers at universities of applied sciences could be included to cover all segments of academia. 


\section{Acknowledgements}

The authors would like to thank three anonymous reviewers for their valuable comments, Jan P. Kramer, Vera Junge, and Andrea Schmidt for their inputs to this paper, as well as the interviewees for spending their time answering the questions. The research producing these results has received funding from the European Community's Seventh Framework Program (FP7/2007-2013) under grant agreement $n^{\circ} 216813$.

\section{References}

AUDRETSCH, D.and FELDMAN, M.P. (1996) R\&D Spillovers and the Geography of Innovation and Production, American Economic Review 86, 630-640.

BACKHAUS, B., NINKE, L. and OVER, A. (2002) Brain Drain - Brain Gain. Eine Untersuchung über internationale Berufskarrieren, Stifterverband für die Deutsche Wissenschaft, Essen.

BEISE M. and STAHL H. (1999) Public research and industrial innovations in Germany. Research Policy 28, 397-422.

BERGMAN, E. and SCHUBERT, U. (2005) Spillovers and innovation, environment and space: policy uncertainties and research opportunities, in MAIER and Sedlacek, S. (Eds) Spillovers and innovations: Space, Environment, and the Economy, pp. 157-177. Springer, Wien.

DAAD (2007) Facts and figures on the international nature of studies and research in Germany, German Academic Exchange Service, Bertelsmann, Bielefeld.

DETTling, D. and JÖRGENSEN, J. (2004) Push- und Pull-Faktoren des Brain-Drain, Berlinpolis, Berlin.

DIETZ, J. and BOZEMAN, B. (2005) Academic careers, patents, and productivity: industry experience as scientific and technical human capital, Research Policy 34, 349-367. 
DIW (2008) Auswanderung von Deutschen: kein dauerhafter Verlust von

Hochschulabsolventen, Wochenbericht des DIW 75(5), 49-55.

DOCQUIER, F. and MARFOUK, A. (2004) Measuring the international mobility of skilled workers (1990-2000) - Release 1.0, World Bank Policy Research Working Paper WPS3381, Washington.

DOERING, T. and SCHNELLENBACH, J. (2006) What do we know about geographical knowledge spillovers and economic growth? A survey of the literature, Regional Studies 40, 375-395.

DTI (2002) Knowledge migrants: the motivations and experiences of professionals in the UK on work permits, Department of Trade and Industry, London.

ENDERS, J. and MUGABUSHAKA, A.M. (2004) Wissenschaft und Karriere - Erfahrungen und Werdegänge ehemaliger Stipendiaten der DFG, Deutsche Forschungsgemeinschaft, Bonn.

EUSTACE, C. (2000) The intangible economy: impact and policy issues, European Commission, Brussels.

FLORIDA, R. (2002) The rise of the creative class, Basic Books, New York.

FRENKEN, K., HARDEMAN, S. and HOEKMAN, J. (2009) Spatial scientometrics:

Towards a cumulative research program, Journal of Informetrics 3(3), 222-232.

FRITSCH, M. and SCHWIRTEN, C. (1998) Öffentliche Forschungseinrichtungen im regionalen Innovationssystem, Raumforschung und Raumordnung 56(4), 253-263. FRITSCH M. and SLAVTCHEV, V. (2005) The Role of Regional Knowledge for Innovation, Paper presented at the 45th ERSA Conference, Amsterdam, Netherlands, August 23-27, 2005. FURUKAWA, R. and GOTO, A. (2006) Core Scientists and innovation in Japanese electronics companies, Scientometrics 68(2), 227-240.

HOROWITZ, I. (1966) Some aspects of the effects of the regional distribution of scientific talent on regional economic activity, Management Science 13(3), 217-232. 
IOANNIDIS, J.P.A. (2004) Global estimates of high-level brain drain and deficit, Journal of the Federation of American Societies for Experimental Biology, 18, 936-939.

JAFFE, A., TRAJTENBERG, M., and HENDERSON, R. (1993) Geographic localization of knowledge spillovers as evidenced by patent citations, Quarterly Journal of Economics 108(3), 577-598.

JÖNS, H. (2007) Transnational mobility and the spaces of knowledge production: a comparison of global patterns, motivations and collaborations in different academic fields, Social Geography 2, 97-114.

KOPPEL, O. and PLÜNNECKE, A. (2008) Braingain - Braindrain: Die

Wachstumspotenziale der Zuwanderung, IW-Positionen 33, Institut der deutschen Wirtschaft, Köln.

KRAMER, J., REVILLA DIEZ, J., MARINELLI, E. and IAMMARINO, S. (2009) Intangible Assets, Multinational Enterprises and Regional Innovation in Europe, IAREG Working Paper $1.3 \mathrm{~b}$, Hannover.

LAM, A. (2007) Knowledge networks and careers: academic scientists in industry-university links, Journal of Management Studies 44(6), 993-1016.

MAHROUM, S. (2000a) Scientific Mobility: An Agent of Scientific Expansion and Institutional Empowerment, Science Communication 21(4), 367-378.

MAHROUM, S. (2000b) Highly skilled globetrotters: mapping the international migration of human capital, R\&D Management 30(1), 23-31.

MAHROUM, S. (2005) The International Policies of Brain Gain: A Review, Technology Analysis \& Strategic Management 17(2), 219-230.

MAIER, G., KURKA, B. and TRIPPL, M. (2007) Knowledge spillover agents and regional development - spatial distribution and mobility of star scientists, DYNREG Working Paper 17/2007, Vienna. 
MIGUELEZ, E., MORENO, R. and SURINACH, J. (2009) Scientists on the move: tracing scientists' mobility and its spatial distribution, Research Institute of Applied Economics Working Paper 2009/16, University of Barcelona.

MORENO, R., PACI, R. and USAI, S. (2005) Spatial spillovers and innovation activity in European regions, Environment and Planning A 37, 1793-1812.

OECD (2008) The global competition for talent. Mobility of the highly skilled, OECD, Paris. PRITCHARD, R. (2006) Trends in Restructuring German Universities, Comparative Education Review 50(1), 90-112.

POLANYI, M. (1966) The Tacit Dimension, Doubleday, New York.

POWER, D. and MALMBERG, A. (2008) The contribution of universities to innovation and economic development: in what sense a regional problem?, Cambridge Journal of Regions, Economy and Society 1, 233-245.

PROGNOS (2008) Gründe für die Auswanderung von Fach- und Führungskräften aus Wirtschaft und Wissenschaft, Prognos AG, Basel.

REINER, C. (2010) Brain competition policy as a new paradigm of regional policy: A European perspective, Papers in Regional Science 89(2), 449-461.

REVILLA DIEZ, J. (2000) The importance of public research institutions in innovative networks - empirical results from the metropolitan innovation systems Barcelona, Stockholm and Vienna, European Planning Studies 8(4), 451-463.

SAXENIAN, A.(2005) From brain drain to brain circulation: transnational communities and regional upgrading in India and China, Comparative International Development 40(2), 35-61. SAXENIAN, A.(2006) The new argonauts. Regional advantage in a global economy, Harvard University Press, Cambridge.

SCHILLER, D. (2011) Institutions and practice in cross-sector research collaboration: conceptual considerations with empirical illustrations from Germany, Science and Public Policy, DOI: 10.3152/030234211X12924093660075. 
SCHILLER, D. and REVILLA DIEZ, J. (2010) Local embeddedness of knowledge spillover agents: Empirical evidence from German star scientists, Papers in Regional Science 89(2), 275-294.

SIEGEL, D., WRIGHT, M. and LOCKETT, A. (2007) The rise of entrepreneurial activity at universities: organizational and societal implications, Industrial and Corporate Change 16(4), 489-504.

SOLIMANO, A. (2008) Causes and consequences of talent mobility, in SOLIMANO, A. (Eds), The international mobility of talent. Types causes and development impact, pp. 1-19, Oxford University Press, New York.

STAM, E. (2007) Why Butterflies Don't Leave. Locational behavior of entrepreneurial firms, Economic Geography 83(1), 27-50.

WRIGHT, M., CLARYSSE, B., MUSTAR, P. and LOCKETT, A. (2007) Academic Entrepreneurship in Europe, Edward Elgar, Cheltenham.

ZUCKER, L. and DARBY, M. (2006) Movement of star scientists and engineers and hightech firm entry, NBER Working Paper No. 12172, April 2006.

ZUCKER, L., DARBY, M. and BREWER, M. (1998) Intellectual human capital and the birth of U.S. biotechnology enterprises, American Economic Review 88(1), 290-306. 
Table 1: Main reasons for German scientists to go abroad

\begin{tabular}{lcccc}
\hline \multirow{2}{*}{ Reason } & \multicolumn{5}{c}{ Ranking in different studies } \\
& (a) & (b) & (c) & (d) \\
\hline Better career opportunities abroad & 1 & 1 & 3 & - \\
Lack of career opportunities in Germany & 2 & 2 & 4 & - \\
Collaboration with renowned scientists & - & - & 1 & 1 \\
Deepening of skills and knowledge & - & - & 2 & - \\
Matter of course for career advancement & - & - & - & 3 \\
Improvement of job perspectives in Germany & - & - & 6 & 2 \\
Better equipment than in Germany & - & - & 5 & 4 \\
Personal reasons & 3 & 4 & 7 & - \\
Better income situation & - & 3 & 8 & - \\
\hline
\end{tabular}

Source: own compilation based on (a) DETTLING and JÖRGENSEN, 2004; (b) PROGNOS, 2008; (c) BACKHAUS et al., 2002; (d) ENDERS and MUGABUSHAKA, 2004 
Table 2: Star scientists interviewed according to scientific field

\begin{tabular}{lccc}
\hline & Total & $\begin{array}{c}\text { Highly } \\
\text { Cited }\end{array}$ & $\begin{array}{c}\text { Clusters of } \\
\text { excellence }\end{array}$ \\
\hline Total & 25 & 19 & 6 \\
Life Sciences & 5 & 4 & 1 \\
Chemistry & 3 & 2 & 1 \\
Pharmacology & 4 & 4 & 0 \\
Mathematics/Physics & 7 & 6 & 1 \\
Engineering & 6 & 3 & 3 \\
\hline
\end{tabular}

Source: own survey 
Table 3: Time spent abroad and main spatial scope of knowledge flows (no. of scientists, multiple answers possible), $\mathrm{n}=25$

\begin{tabular}{lcccccccccc}
\hline \multirow{2}{*}{$\begin{array}{c}\text { Type of knowledge } \\
\text { flow }\end{array}$} & \multicolumn{3}{c}{$>$ y years abroad } & \multicolumn{3}{c}{$\begin{array}{c}1-3 \text { years } \\
\text { abroad }\end{array}$} & \multicolumn{3}{c}{ Not abroad } \\
\cline { 2 - 11 } & L & N & I & L & N & I & L & N & I \\
\hline Scientists in sub-group & & 13 & & & 9 & & & 3 & \\
Scholar-to-scholar & 11 & 3 & 8 & 2 & 4 & 6 & 2 & 0 & 2 \\
Scholar-to-industrialist & 4 & 5 & 6 & 2 & 6 & 3 & 2 & 3 & 0 \\
Scholar-to-entrepreneur & 7 & 0 & 2 & 1 & 0 & 0 & 3 & 0 & 0 \\
Scholar-to-student & 8 & 2 & 7 & 8 & 2 & 2 & 3 & 0 & 0 \\
\hline L - local, N - national, I - international & & & & & & &
\end{tabular}

Source: own survey 
Figure 1: Potential impact of star scientists on intangible assets and related knowledge flows

\begin{tabular}{|c|c|c|c|c|}
\hline \multicolumn{2}{|c|}{$\begin{array}{l}\text { Industrial network capital: } \\
\text { scholar-to-industrialist flow }\end{array}$} & & \multicolumn{2}{|c|}{$\begin{array}{l}\text { Scientific network capital: } \\
\text { scholar-to-scholar flow }\end{array}$} \\
\hline $\begin{array}{l}\text { Personal } \\
\text { transfer }\end{array}$ & $\begin{array}{c}\text { Direct } \\
\text { collaboration }\end{array}$ & \multirow{2}{*}{$\begin{array}{c}\text { Star } \\
\text { scientist }\end{array}$} & $\begin{array}{l}\text { Personal } \\
\text { transfer }\end{array}$ & $\begin{array}{c}\text { Direct } \\
\text { collaboration }\end{array}$ \\
\hline $\begin{array}{l}\text { Commercialization } \\
\text { of research }\end{array}$ & $\begin{array}{l}\text { Initiation of } \\
\text { start-ups }\end{array}$ & & $\begin{array}{l}\text { Attraction } \\
\text { and inspiration }\end{array}$ & $\begin{array}{l}\text { Training of } \\
\text { students }\end{array}$ \\
\hline \multicolumn{2}{|c|}{$\begin{array}{c}\text { Entrepreneurship capital: } \\
\text { scholar-to-entrepreneur flow }\end{array}$} & & \multicolumn{2}{|c|}{$\begin{array}{l}\text { Human capital: } \\
\text { scholar-to-student flow }\end{array}$} \\
\hline
\end{tabular}

Source: own draft 